\title{
Comparison of Internal Control Systems in Japan and China
}

\author{
Sato Takahiro \\ Research Center of Enterprise and Corporate Law of Peking University \\ Beijing, China \\ E-mail:sato.zuoteng.boo@gmail.com \\ Pan Jia (Corresponding author) \\ Hebei University \\ Baoding City, Hebei Province, China \\ E-mail: pjpj99@foxmail.com
}

Received: October 28, 2011

Accepted: November 14, 2011 Published: January 5, 2012

doi:10.5430/ijba.v3n1p66

URL: http://dx.doi.org/10.5430/ijba.v3n1p66

\begin{abstract}
In Japan, "Corporate Law" and "Financial Instruments and Exchange Law" stipulate the internal control system. Stipulations in "Corporate Law" tend towards all levels the in the company, while stipulations in "Financial Instruments and Exchange Law" are more inclined towards the accuracy of financial reporting. Although the internal control systems stipulated by these two laws have many of differences, their essence is the same: perfecting a comprehensive internal control system. In order to safeguard the normal operation of internal control system, provisions in the law require that directors act in due diligence toward establishing an internal control system.
\end{abstract}

Keywords: Internal Control, Sino-Japan Comparison, the Duty of the Diligence

These days, many people are talking about how to control financial security. One strategy is to improve the internal control system that was first put forward in the United States. The current representative outline, the COSO report (Internal control-Integrated Framework), has reached maturity, and the basic framework for internal control systems has already been formed. The report concluded that internal control systems have the following features: (1) effectiveness and efficiency of operations; (2) reliability of financial reporting; (3) compliance with applicable laws and regulations.

Internal control systems can be divided into five parts: (1) the control environment; (2) risk assessment; (3) control activities; (4) information and communication; and (5) monitoring. Control environment means a control atmosphere that constitutes a unit and is the foundation of the impacting other part of internal control. Risk assessment is the identification and analysis of the internal and external risks, which may affect the management, financial reporting, and legal compliance. Control activities refer to the necessary measures to the identified risks and the policies and procedures that ensure the unit's objectives are achieved. Information and communication means that in order to enable employees to fulfill their responsibilities, enterprises must identify and exchange the external and internal information. Monitoring is the evaluation process of the quality of the internal control; that is, evaluating both the operations of internal control system and the improvement activities (Zhu, 2009, p. 7-8). The significance of the COSO report is that it changed the concept of using an external supervisory body to carry out the internal control systems to a concept of using the managers themselves to carry out the internal control system (Kobayashi, 2007, p. 41).

For companies, an internal control system is a necessity. Without it, they will have difficulty achieving normal operations. For example, when a company is preparing a financial report, its contents need to comply with the law, and to know how to do this, it is necessary to establish an internal control system. In addition, preventing environmental problems requires a company to establish an internal risk management system, and for companies, an internal control system can be considered as both a risk management system as well as a basic management system. Even in situations where there are no legal obligations, it is still necessary for companies to establish an internal control system. Especially as a company expands, it becomes more difficult for managers to control the all of the management problems. The internal control system is a basic system that every company should have, but in recent years, the corporate scandals in the United States and Japan have made people pay more attention to its functions. Now many other countries are 
building internal control legal systems. Major corporate scandals such as Enron in the United States triggered the establishment of "Sarbanes-Oaks legislation" (SOX Act), strengthened the external auditing of companies, information disclosure system, and other relevant corporate governance stipulations. Section 302 of the SOX Act requires companies to establish a financial reporting disclosure internal control; Section 404 stipulates the requirements of the internal control system: (1) Management publishes an annual report on the internal control system; (2) Management of listed companies evaluate the effectiveness of the internal control system; (3) The accounting firm in charge of auditing the annual financial report will also test and evaluate the internal control system, and also issue an evaluation report. In addition to the U.S., Japan, based on several judicial precedents, in the "Corporate Law" and "Financial Instruments and Exchange Law" stipulates the contents of the legal system for internal controls.

In China, "Internal Control and Audit Risk” was promulgated in 1997 to implement auditing standards. Also, the Bank of China promulgated "The Guiding Principles of Strengthening the Internal Controls of Financial Institutions " in May 1997. In 1999, Section 27 of the revised "Accounting Law" put forward certain requirements of the internal control system, such as position separation, authorization approval, property control and internal auditing. In 2006, the Ministry of Finance, the State-owned Assets Supervision and Administration Commission, China Securities Regulatory Commission, China Insurance Regulatory Commission, China Banking Regulatory Commission, and the Audit Commission, established the National Internal Control Standards Committee. In March 2007, they promulgated the basic guidelines of internal control. In June 2008, the Ministry of Finance and four other ministries and committees, promulgated "Basic Norms of Internal Control". These norms was implemented among listed companies on July 1, 2009 to encourage its implementation in non-listed medium-sized enterprises (Zhu, 2009, p. 9). On April 26, 2010, the Ministry of Finance, China Securities Regulatory Commission, Audit Commission, China Banking Regulatory Commission, and China Insurance Regulatory Commission established "The Guidelines for the Internal Control of Companies”, which contains: “Application Guidelines for the Internal Control of Companies”, "Evaluation Guidelines for the Internal Control of companies", and "Auditing Guidelines for the Internal Control of Companies". The promulgation of "Basic Norms of Internal Control" and "The Guidelines for the Internal Control of Companies" marked the establishment of internal controls in companies in China. To improve the set up of the internal control system in listed companies, the Ministry of Finance and four other commissions established a timetable for the internal control system's implementation. The internal control system will first be implemented in listed companies on January 1, 2011, and will expand to listed companies on the Shanghai Stock Exchange and Shenzhen Stock Exchange on January 1, 2012. Based on this, it will be carried out in the companies randomly. Meanwhile, the advance implementation of the large and medium enterprises will be encouraged (White Paper, 2010).

In wake of this trend, comparing the internal control systems between countries may hold some significance. Following, we first introduce the legislative background of the internal control system in Japan, then briefly introduce the legal system of internal controls in Japan, and finally compare the legal systems of internal controls in China and Japan.

\section{The Legislative Background of the Internal Control System in Japan}

In the past, Japanese Corporate Law scholars were in general agreement that internal controls are a management system determined independently by the company manager. Moreover, there was no fixed form for setting up the internal control system, and it did not require law (Japan Association of Corporate Directors, 2008, p. 61). But this viewpoint fundamentally changed after the Daiwa Bank judgment in 2000. An employee at the New York branch of Daiwa Bank conducted financial business that resulted in a loss of about 1.1 billion U.S. dollars. Daiwa Bank concealed the incident from the U.S. authorities, which resulted in a \$340 million fine. Later, in Japan, Daiwa Bank shareholders, considering this a violation of the bank's obligation to establish an internal control system, filed a shareholder lawsuit. The court ruled that the directors of the New York branch, the Inspection Department Directors, and the auditors, who were obligated to supervise the New York branch, had all violated the obligation to establish an internal control system, and it ordered the 11 directors to pay $\$ 775$ million USD as compensation. The judicial precedent set by this ruling had a huge impact on the Japanese economic world. The economic sector later called on political field to amend "Commercial Law", which after it was amended, saw an increase in sections relating to director liabilities, thereby limiting the duties of directors. In another case, case of the Kobe Steel, Ltd., the court considered that the functions in large enterprises are extremely different, making it hard for directors to grasp the situation of the other directors or employees. In this situation, the directors should set up an internal control system to maintain normal management. It was ruled that it is the directors' obligation to establish an internal control system. These two judicial precedents set the foundation for the internal control system. In addition to these judicial precedents, the Tokyo Stock Exchange has its own regulations relating to internal controls. After January 2005, listed companies on the Tokyo Stock Exchange were required to submit a letter confirming the accuracy of the Securities Report and Mid-term Report records. The recorded contents of a Securities Report are the company's name, the situation with the enterprise group that owns the company, its financial 
situation, and other important business related issues (Kobayashi, 2007, p. 51). This approach was drawn from "Financial Instruments and Exchange Law."

As mentioned above, although the internal control system regulations were not legislated in Japan, they existed as a judicial precedent or in the form of the stock exchange's regulations. Currently, "Corporate Law" and "Financial Products Exchange Law" also stipulates the internal control system. The main background of these two laws stipulating an internal control system was the Seibu Railway Company submitting false records in their securities report in 2004. In 2003, the Legislative Council's sub-council on corporate law released "Draft Outline for the Modernization of Corporate Law". The draft did not include content on internal control, but following the Seibu Railway scandal, it did (Kobayashi, 2007, p. 42). According to the regulations of the Japanese stock exchange, if the shares of the 10 largest shareholders of a listed company exceed $80 \%$ of the total shares, the company will be delisted from the market. The largest shareholder in Seibu Railway is Kokudo Company. To avoid delisting, for a long time, Seibu Railway faked shares held by individuals, and submitted false records in their securities report in June 2004, which were later discovered. To avoid delisting, and to follow the regulations of Stock Exchange, the Kokudo Company chairman made the false records public after selling some of Seibu Railway shares. In August 2004, in the meeting of Seibu Railway's directors, auditors raised the problem and the board of directors also demanded investigating Kokudo, but Kokudo exerted pressure on them. When the general manager of Seibu Railway Company in Kokudo asked Seibu Railway Company to sell its shares held by Kokudo, he thought this was akin to insider trading and refused, but Kokudo made the deal anyway. After legal examination, the court held that the chairman of Kokudo, Kokudo, and Seibu Railway Company had all violated the "Securities and Exchange Law" because of the insider trading. The court fined the chairman of Kokudo 2 million yen and sentenced him to a suspended term of imprisonment. Kokudo was fined 150 million yen and Seibu Railway Company was fined 200 million yen. Seibu Railway Company was delisted in December 2004 (Ootani, 2007, p. 268). In this case, although Seibu Railway Company's the auditors and directors felt that there may be some problems, the heads of the parent company had the power to act illegally. Some people hold the following two points about false records problem: (1) the internal control system was not effective; (2) compared with the foreign corporate scandals, it took too short a time to evaluate internal controls during the financial examination (Japan Association of Corporate Directors, 2008, p. 90).

Japan's "Corporate Law" and "Financial Instruments and Exchange Law" stipulate some contents of the internal control system because of the Seibu Railway scandal, so we believe that this event has greatly impacted the legislation of internal controls in Japan. In addition to the Seibu Railway scandal, the legislative background of the internal control system is the publication of "Corporate Law" in 2005. The new "Corporate Law" expanded the freedom of companies, meaning that opportunities to abuse power increased. Inhibiting the abuse of power needs companies to strengthen internal controls, which may be one of the reasons for the strengthening the internal controls in Japan.

\section{Comparing the Stipulation of Internal Controls in Japan's “Corporate Law” and "Financial Instruments and Exchange Law”}

In Japan, both "Corporate Law" and "Financial Instruments and Exchange Law" include the stipulations on the internal control system. Stipulations in "Corporate Law" tend towards all levels of the company, while the stipulations in "Financial Instruments and Exchange Law" are more inclined towards the accuracy of financial reports. The following section will briefly present the legal stipulations of internal controls.

\section{1 "Corporate Law”}

"Corporate Law" stipulates that the board of directors at large companies and companies with committees set up the internal control system. In Japan, there are two company models: a company with board of auditors, and a company with committees. Companies themselves choose their corporate governance model. The former is the traditional Japanese corporate governance model, where the board of directors and the board of auditors have a parallel relationship; the latter is the United States-based corporate governance model, which does not include the board of auditors. However, the board of directors does include auditing, nomination and compensation committees, and the function of audit committee and the board of auditors is roughly the same. Currently, there are more Japanese companies with a board of auditors than with committees. Companies with committees are considered as the company form where the monitoring function and the executive function are separated, therefore managers must closely observe the law. In this corporate governance model, internal controls are strengthened, and relevant stipulations have been established. Some scholars believe that the stipulations for the internal control system in "Corporate Law" are for large companies, because the larger a company is, the more difficult it is for directors to monitor its activities. As to why companies with committees should establish an internal control system (Kobayashi, 2007, p. 157). "Corporate Law" defines internal controls as "the development of systems necessary to ensure that the execution of duties by directors complies with laws and regulations, the articles of 
incorporation, and other systems prescribed by the applicable ordinances of the Ministry of Justice as systems necessary to ensure the properness of operations of a Stock Company ". It also stipulates that the internal control system should be determined by the board of directors, which only needs to determine the principles of internal controls, so they can decide which internal control contents not to set up. If the company does not establish internal controls, it will not be fined for violating "Financial Instruments and Exchange Law", but if it does not submit a legal report or it submits reports that include false contents it will be fined (Aizawa, 2006, p. 334). It is important that internal controls are decided by the board of directors, and not by representative directors or others.

In Article 101 of "Ordinance for Enforcement of Corporate Law", the internal control system is defined as the follows: (1) to ensure that the duties of the director or executive officer comply with the laws and regulations of the system; (2) to preserve the system's duty information; (3) to stipulation for loses of risk management, etc.; (4) to ensure duties are being implemented effectively; (5) to ensure that employees' duties comply with the laws and regulations of the system; (6) to ensure the appropriateness of the companies of the enterprise groups, companies formed by stock companies, parent companies, or subsidiary companies. "Financial Instruments and Exchange Law" contains important content for improving internal controls of subsidiary companies in according to "On the Setting of the Standards and Practice Standards for Management Assessment and Auditing Concerning Internal Control Over Financial Reporting", which says, in principle, the evaluation of internal controls is carried out together with subsidiary companies. Therefore, we need to consider the situation of subsidiary companies or related companies when preparing the scope of evaluation on internal controls in financial report. It is important to ensure the appropriateness of the overall business, but it should be done by each company, because in both the parent company and the subsidiary company, the legal persons are all independent. From this perspective, some people think that the directors of the parent company are limited in interfering with the business of subsidiary companies (Kobayashi, 2007, p. 94).

Article 103 of "Ordinance for Enforcement of Corporate Law" stipulates the four contents of the internal control system: (1) the auditor requesting an assistants to help in their duties; (2) assistants to the auditor are independent from directors; (3) directors or employees reporting to the auditors; (4) ensuring that other auditors can supervise effectively. Paragraph 3 of article 103 regards companies with a board of auditors, and the regulation also stipulates a similar content for companies with committees. But the contents of this regulation are different from the one on companies with a board of auditors: the board of directors will not consider setting up an assistant until the auditors asks for it to assist their duties. The regulation on companies with committees does not mention the words of "asks for ". As for the differences, from the perspective of ensuring the independence of auditors, legislators explain that it's inappropriate to set up an assistant if the auditors do not require it. In companies with committees, the members of the committee are different from the members of the board of auditors: they are not specific staff and are mostly independent directors. Moreover, from a legal point of view, setting such assistants is an arbitrary decision for the company with committees. Therefore, from this perspective, the stipulations on models of the two companies are the same. Another difference is that assistants in companies with committees include workers and directors. The introduction of these stipulations is needed for sharing information among the auditing, nomination and compensation committees. For this requirement, in company with committees that take independent directors as the core role, some people think that independent directors have an interest to each other because of their assessment to the other, so this situation easily impairs the equality of the independent directors (Xiaolin, Xiuzhi, 2007, p. 189). According to a survey conducted by the Japan Association of Corporate Directors, of the 67 companies with a board of auditors and 18 companies with committees, two-third of companies with board of auditors had set up assistants, while all of the companies with committees had done it. From this we can see that it's common to set up assistants in large companies (Japan Association of Corporate Directors, 2008, p. 129).

After large companies and company with committees decide on the contents of the internal control system (according to the board of directors' resolution), the contents are recorded in the business report. The auditors or auditing committee review the business report and write down evaluations in the auditing reports. They need to evaluate business legitimacy and they also should evaluate the internal control system at the same time, therefore, their audit includes both a legitimacy audit and a validity audit. The common consensus is that the auditor's monitoring scope is limited to legitimacy audit, but it does not include validity audit to business judgments of the directors. However, according to "Corporate Law", auditors should supervise internal control matters, and they must supervise business decisions within a certain range (Kobayashi, 2007, p. 129).

\section{2 "Financial Instruments and Exchange Law"}

According to "Financial Instruments and Exchange Law", listed companies that submit securities reports and other companies under this decree, must submit financial statements for themselves and their company-owned enterprise 
groups each business year. They should also submit other evaluation reports, set up in accordance with the provisions of the Cabinet Office to ensure the appropriateness of the information. The evaluation systems should be defined as the systems that make the company's financial reports comply with the law. Financial reports under this definition are the various financial statements and the external reports related to the information that has a significant impact on the reliability of these statements. Moreover, The scope of "Financial Instruments and Exchange Law" is larger than the one stipulated in the "SOX Act". This is because in the U.S. the evaluation scope is limited to financial statements and annotations. But in Japan, as mentioned above, the Seibu Railway scandal was not about falsified financial statements; it was about false records of the major shareholders situation. If the evaluation scope were only limited to matters affecting the reliability of the financial statements, this narrowness would cause problems (Japan Association of Corporate Directors, 2008, p. 93). This report, known as the "internal control report", should be supervised by an accounting firm. According to "Financial Instruments and Exchange Law", managers should first set up an internal control system, and then conduct self-evaluations and write internal control reports. Afterwards, the accounting firm supervises it and writes an internal control auditing report. Finally, the company will disclose the internal control report. In the U.S., auditors write the internal control auditing report directly, but this requires a lot of supervision and monitoring costs are high. As compared with the internal control system in the U.S., the focus of the Japanese system is on cost reduction. "Financial Instruments and Exchange Law" also tends toward reducing monitoring costs. Following the example above, under "Financial Instruments and Exchange Law", the company's managers first make a self-assessment on the effectiveness of the internal control so that they can establish the report. Later, the auditing corporation monitors and evaluates the report because the managers know what the risks are, and know where the focus of evaluations should be, so they can make a choice by themselves to reduce the evaluation scope. Thus, it may reduce the cost of self-evaluation. However, in principal, the report shouldn't omit evaluation of business processes in the financial report involving the entire company. In addition, the company in the question determines which parts of the subsidiary company should be evaluated. According to the survey by Japan Associate of Corporate of Directors, 64\% of companies did not recognize some of their subsidiary companies as the objects of evaluation (Japan Association of Corporate Directors, 2008, p. 93). The accounting firm can also supervise according to the managers' evaluation, which may also reduce monitoring costs.

As noted above, "Financial Instruments and Exchange Law"' stipulates the internal control system, and the Japanese government needs to work out corresponding implementation standards for it. In 2007, the Business Accounting Council of FSA Internal Control section publicly announced " On the Setting of the Standards and Practice Standards for Management Assessment and Audit concerning Internal Control Over Financial Reporting" (hereon referred to as "Practice Standards"). Under "Practice Standards ", internal controls, in principal, are a process undertaken by everyone in an organization in order to achieve the following four company objectives: (1) effectiveness and efficiency of business operations; (2) reliability of financial reporting; (3) compliance with applicable laws and regulations relevant to company activities; (4) safeguarding of assets. Compared with the U.S COSO report, the Japanese internal control system adds the "safeguarding of assets" objective. In the COSO report, "safeguarding of assets" is not an independent objective, but it's included under the objective of "effectiveness and efficiency of business operations". In the U.S., various viewpoints existed on whether or not "safeguarding of assets" should be an independent objective. The United States General Accounting Office (GAO) stated that it should be, but ultimately did not make it an independent objective for the following reasons: (1) At that time, many people thought that the implementation of an internal control system would increase the responsibility of the U.S. accountants, so they argued that the objective should not be independent so as to avoid risk; (2) The U.S. already had the "Foreign Corrupt Practices Act" (FCPA), which requires "safeguarding of assets". As such, there was no need to require it as an independent objective in the COSO report. But Japan does not have a law similar to the FCPA, so "Practice Standards " should require the "safeguarding of assets" as an independent objective (Matida, 2008, p. 97). The four objectives listed above consist of the following six basic components: (1) control environment; (2) risk assessment and response; (3) control activities; (4) information and communication; (5) monitoring; (6) response to IT. Compared with the basic components stipulated in the U.S COSO report, Japan's "Practice Standards" adds the "response to IT" component. This is because IT has greatly advanced in the 15-year gap between the U.S. COSO report and the Japanese "Practice Standards". Further, as compared with foreign companies, Japanese companies use IT to a lesser extent, so this component was added to "Practice Standards " (Japan Association of Corporate Directors, 2008, p. 160).

As noted above, managers establish an internal control system, and execute self-evaluations and make internal control reports. Then, accounting firms supervise it and work out internal control audit reports. Additionally, "Financial Instruments and Exchange Law" stipulates that company managers should submit confirmation certifying that the contents of securities reports, quarterly reports, and the interim reports (six months) are accurate. The "Securities and Exchange Act", amended in 2003, stipulates the arbitrary submission of such a confirmation. At the time, the FSA 
required banks and other financial institutions to submit confirmation, which they did, but it was not required for non-financial institutions to submit confirmation. However, after the Seibu Railway scandal, the FSA required all the listed companies to check the contents of submitted securities reports. As a result, more than 500 companies modified the contents of their records, although many doubt the reliability of these reports. In these situations, "Financial Instruments and Exchange Law" stipulates that a company's managers are obligated to submit confirmations (Kobayashi, 2007, p. 134). In summation, the "Financial Instruments and Exchange Law" ensures the accuracy of financial reporting through: (1) securities reports; (2) managers' confirmation on securities reports; (3) managers' self-assessment reports on the internal control systems, and the internal control reports compiled by managers; (4) internal control audit reports made by accounting firms done through evaluating the internal control reports.

\subsection{Differences between "Corporate Law" and "Financial Instruments and Exchange Law"}

"Corporate Law" and "Financial Instruments and Exchange Law" both have stipulations on the internal control system, but there are differences between the two laws: (1) the former mainly applies to large enterprises, while the latter applies to listed companies; (2) internal control stipulations in the former are larger in scope, covering most areas, while the latter is mainly for the areas relating to the reliability of financial reporting; (3) internal control in the former is established and taken responsibility of by the board of directors, while in the latter the responsibility is taken by company managers; (4) the former stipulates that the internal control system should be monitored by accounting companies or the audit committee, while in the latter, the internal control system should be monitored by accounting companies; (5) The former stipulates that the contents of the internal control should be recorded in the business report and be evaluated in the audit reports made by board of auditors or audit committee, while the latter stipulates that the contents of the internal control should be recorded in the internal control report and be evaluated in the internal audit reports; (6) the contents of the internal control system in the former are determined by the board of directors, and whether to establish the internal control system is arbitrary and it dose not require evaluation, while in the latter, managers must evaluate the internal control; (7) there are also differences in the criminal responsibilities such as, the former stipulates that there will be 1 million yen fine in the false records, while the latter stipulates tht it's a crime of falsifying records. The individual has a 5-year imprisonment, or is fined a maximum of 5 million yen. Legal persons will be fined fewer than 500 million yen, and it also stipulates administrative penalties. It's easy to see that the punishment in latter is much heavier.

As mentioned above, although the internal control systems stipulated by the two laws have a lot of differences, their essence is the same. The "Financial Instruments and Exchange Law" focuses on ensuring the reliability of financial reporting, and, in order to ensure this, it dose not just concern itself with financial matters, but focuses on the entire process of running the company, so as to perfect the comprehensive internal control system. In this way the essence of internal controls stipulated in "Financial Instruments and Exchange Law" and "Corporate Law" are the same (Ozaki, 2008, p. 26). In comparison, "Corporate Law" stipulates the appropriateness of the supervisory functions toward the accounting firms or the auditing committee, as the internal control contents of the financial reporting are also evaluated in the auditing reports. Also the "Financial Instruments and Exchange Law" stipulates that the duty of auditors is a "control environment" factor in the internal control system, therefore, accounting firms should evaluate the activities of the corporate auditors or the auditing committee. Since they evaluate each other, these two laws stipulations form a complementary relationship (Kobayashi, 2007, p. 18). Although, according to "Financial Instruments and Exchange Law", the internal control report (evaluating the effectiveness of internal control) is edited by the managers, and accounting firms also edit the internal control report, so "Corporate Law" stipulates that the monitoring activities of board of auditors should be evaluated by the accounting firm and the managers. From this relationship, they all care about their own evaluation, so if the relationship is bad, they cannot monitor strictly or evaluate accurately (Kobayashi , 2007, p. 183).

\section{Sino-Japan Comparison}

In July 2006, the Chinese Ministry of Finance, State-owned Assets Supervision and Administration Commission, China Securities Regulatory Commission, the Audit Commission, the China Banking Regulatory Commission and China Insurance Regulatory Commission jointly established the National Internal Control Standards Committee. In November in the same year, that Committee issued "Internal Control Standards - Basic Standards" and drafts of the 22 specific norms. On June 28, 2008, five ministries and committees issued "Basic Norms of Internal Control", which was implemented for listed companies on July 1, 2009. Implemented by other non-listed enterprises was also encouraged. As defined by "Internal Control Standards: Basic Standards", internal controls are implemented by directors, auditors, managers and staff. The internal control system has five objectives: (1) ensure that the enterprise management is legally compliant; (2) ensure the safety of business assets; (3) ensure that financial reporting and related information are 
accurate and complete; (4) improve the efficiency and effectiveness of operations; (5) promote the enterprise to achieve development strategies. Compared with the targets set in the COSO report, this system includes the "security of assets". Some scholars believe that this internal control system has still not completely conformed to the property rights reforms for China's state-owned enterprises, therefore it must protect national assets from illegal occupation (Li, 2008, p. 36). When comparing the above "Basic Standards" with Japan's internal control system we see the following differences:

\subsection{Scope of Application for Companies}

The Japanese "Financial Instruments and Exchange Law" applies to listed companies, and "Corporate Law" applies to large companies and company with committees, while Article 2 of "Basic Standards" in China states that it is applicable to listed companies and large and medium-sized enterprises.

\subsection{Obligation to Establish an Internal Control System}

Japanese "Corporate Law" requires the board of directors of large companies and companies with committees to decide on internal controls by resolution, but it does not stipulate an obligation to establish an internal control system. In China, Article 12 of "Basic Standards" stipulates that the board of directors is obligated to establish an internal control system.

\subsection{Requirement of Evaluating the Internal Control System}

According to the Japanese "Corporate Law", the contents of the internal control system are recorded in business reports after the board of directors decides on it. Nevertheless, it's also evaluated by auditors in companies with a board of auditors, or it's evaluated and recorded by the audit committee in company with committees. In China, article 12 of "Basic Standards" stipulates that, "the board of auditors should supervise the board of directors to establish and implement internal controls", and Article 13 stipulates that, "enterprises should establish an auditing committee under the board of directors to review the internal control and monitor the implementation and self-evaluation". We can see that board of auditors and audit committees supervise the internal control system. Therefore, the allocation of power between them is a problem worth taking into consideration.

In Japan, the board of directors writes the business report and the board of auditors evaluates it as well as writing and auditing report. So, the board of auditors or audit committee must use the written evaluation report on the internal controls written by the board of directors to write their auditing report. In China, "Evaluation of Internal Control Guidelines" (draft) requires that the internal evaluation report is written annually. The board of directors or auditing committee conducts the evaluation, while the board of auditors supervises it. In addition, Article 62 of "Internal Control Guidelines for Listed Companies on the Shenzhen Stock Exchange" stipulates that: "The board of auditors and independent directors should give advice on the self-assessment report of internal controls". "Information Disclosure Format Standard in Listed Companies - Content and Format of the Annual Report \#2" requires that the board of auditors for listed companies writes reports, but information on the internal control system is rarely disclosed. According to the investigation by Wu Guoping, only 68.52\% of companies disclose this information (Wu, 2008, p. 52). It is apparent that auditors in China do not have include an evaluation of internal controls in their auditing reports, which is much different from in Japan. But Article 9 of the "Interim Regulations on the Board of Auditors of State-Owned Enterprises", promulgated in 2000 stipulates that: "the board of auditors should write the auditing report in a timely manner after checking on the business", therefore auditors in state-owned enterprises may write evaluations on the effectiveness of internal controls.

\subsection{Auditors Verification and Evaluation Of Company's Self-Assessment Report}

According to "Financial Instruments and Exchange Law" in Japan, managers establish internal controls and write self-evaluations, and then write an internal controls report. The report will be made public when the accounting firm finishes evaluating and compiling their internal control audit report. In China, Article 46 of "Basic Standards" stipulates: "Regarding the internal monitoring situation, enterprises should prepare a self-assessment on the effectiveness of internal controls regularly and issue self-assessment reports on the internal control system". It is also stipulated in "Evaluation of Internal Control Guidelines” (Draft): "Internal control evaluation is a process implemented by the board of directors and management that evaluates the effectiveness of internal controls and forms evaluation findings and issues reports." From these stipulations, it's difficult to know whether the auditors verify and evaluate the self-assessment reports of internal control issued by the state-owned enterprises, or whether they act independent of the self-assessment reports, preparing other evaluations. In this regard, Article 32 in "Internal Control Guidelines for Listed Companies on the Shanghai Stock Exchange" stipulates: "When the board of directors discloses the annual report, the annual internal controls self-assessment report and certified public accountant's verification opinion should be disclosed at the same time." Article 33 of this guideline also stipulates: "Referring to the relevant stipulations of the relevant departments, accounting firms should verify and evaluate the self-assessment reports of internal control”. From this 
requirement, accounting firms should verify and evaluate the internal control self-assessment reports, but Article 10 in "Basic Standards" stipulates: "Based on these Standards and related supporting regulations, the accounting firm that accepts the enterprise entrustment should monitor the establishment and implementation of internal control." Furthermore, Article 66 in "Internal Control Guidelines for Listed Company on the Shenzhen Stock Exchange" stipulates: "Companies should submit self-assessment reports of internal control and the evaluation done by certified public accountants to Stock Exchange within the four months after the end of each fiscal year, and disclose them with annual report at the same time”. With these provisions, it's difficult to know whether or not the verification opinions made by the accounting firm are independent from the self-assessment reports of internal control.

Also, managers prepare internal control reports in Japan, while the board of directors prepares and submits self-assessment reports in China.

\section{Conclusion}

There are a variety of differences between internal control systems in Japan and China, but both are a kind of risk management system. It is important for controlling financial risks as well as problems in other areas to set up an effective internal control system. So, what's most important for an internal control system? This depends on who the company is in our society, and what role society expects from it. Gradually, a company will become aware of its role and form the corresponding responsibility to maintain appropriate social behavior. Companies that do not take such action will not achieve sustainable development and will likely be eliminated, as they act in contrary to their social expectations. Therefore, companies also need to build internal controls that correspond to their social responsibility so they can easily recognize the role expected by the stakeholders and take correct actions. This is the social nature of corporate governance and the most important basis for internal control systems. From this point, it may seem that it's difficult for a company to act against its role in society. But actually, it's not because it takes a long time for the company or manager to recognize the social expectation and the concept of responsibility, which is formed through long-term awareness and elimination. During this long process, the company or manager may not accurately recognize its role, and some companies do not accurately recognize the roles that are important for sustainable development, and instead focus on short-term profit and create problems. This also illustrates that an accurate cognition requires a cognitive process of elimination. In reality, these kinds of company created cognitive problems are generally caused by the managers' own cognitive problems. Therefore, it's worth considering how to form an accurate understanding of the role and guide the behavior of managers. A legal system, in which managers bear some responsibility, should be established to improve the cognitive structure. From this view, the stipulations in the law should require the manager has a duty of diligence when establishing internal controls. For example, although the internal control system stipulated in the Japanese "Corporate Law" and "Financial Instruments and Exchange Law" are basically the same, there are great differences in their concept of "duty of the diligence". "Financial Instruments and Exchange Law "focuses on information disclosure, while the internal control system in "Corporate Law" can be regarded as specific manager's duty of diligence (Kanda, 2007, 182). We believe that the duty of diligence in "Corporate Law" is supplementary to "Financial Instruments and Exchange Law".

According to the Japanese "Corporate Law", due to the damage produced by flaws in the internal control system, shareholders or a third party can file actions against directors for violations of the duty of diligence. Article 148 in the Chinese "Corporate Law" also stipulates the duty of loyalty and diligence. In addition, Article 45 of "Basic Standards" stipulates that deficiencies of the internal control system include design flaws and operational deficiencies. Enterprises should rectify these deficiencies and find other defects from the internal supervision measures, and also pursue the responsible people or parties. From this requirement, we can see that members of a board of directors who carry out the resolution to set up an internal control system should also take responsibility when the flaws in the system cause damages in China. According to article 152 and article 153 in the Chinese "Corporate Law", companies and shareholders can take action, but the objective of the internal control system isn't just safeguarding the interests of shareholders; it also contains all other legitimate interests. In this way, the regulations in the Chinese "Corporate Law" contradict the spirit of the internal control system. Taking these circumstances into consideration, we believe that deciding whose rights should be protected, i.e. whether or not to only to protect companies or to contain the third party, is unclear, as is who is entitled to take action. The problems of how to protect the responsibility of third parties and the obligations of directors of establishing the internal controls are very important questions that need to be further researched in the future. 


\section{References}

Aizawa, T. (2006). New Corporate Law. Tokyo: Commercial Law, 334.

Japan Association of Corporate Directors (2008). Responsibility and Status Quo of Internal Control. Tokyo: Association of Tax Accounting, 61-160.

Kanda, H. (2007). Corporate law. Tokyo: Koubunsha, 182.

Kobayashi, H. (2007). Internal Control and Director's Responsibilities, Tokyo: Gakuyoushobou, 18-189.

Li, X. (Ed.). (2008). Basic Norms of Internal Control Review. Dalian: Dalian Press, 36.

Matida, Y. (2008). Knowledge of Internal Control. Tokyo: Nikkei Bunko, 97.

Ootani, Y. (2007). Studying Internal Control Precedents to Prevent Corporate Scandals. Tokyo: Chuokeizai-sha, 268.

Ozaki, Y. (2008). Responsibility and Status Quo of Internal Control. Legal Newsletter, 80(3). 26.

White Paper on Internal Control in Chinese Listed Companies (2010). [Online] Available:

http://news.163.com/10/0902/00/6FHNUBQ100014AED.html

Wu, G. (2008). The Reliability of Internal Control Information. Dongbei Normal University News, Vol. 3, 52.

Zhu, R. (Ed.).(2009). Internal Control Standards and Cases. Beijing: China Economic Times Press, 7-9. 